\title{
Phylogeography and bindin evolution in Arbacia, a sea urchin genus with an unusual distribution
}

\author{
H. A. LESSIOS, * S. LOCKHART,† R. COLLIN,* G. SOTIL, † P. SANCHEZ-JEREZ,§ K. S. ZIGLER,

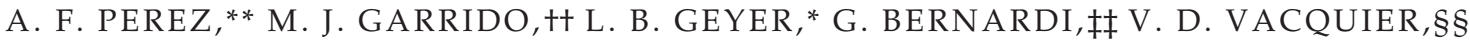 \\ R. HAROUN - and B. D. KESSING*1 \\ *Smithsonian Tropical Research Institute, PO Box 0843-03092, Balboa, Panama, +National Oceanic and Atmospheric \\ Administration, $\ddagger$ Facultad de Ciencias Biológicas, Universidad Nacional Mayor de San Marcos, Lima, Perú, §Departamento de \\ Ciencias Ambientales, Universidad de Alicante, Alicante, España, -Department of Biology, Sewanee: The University of the \\ South, Sewanee, TN, USA, **Departamento de Ecología, Genética y Evolución, Universidad de Buenos Aires, Buenos Aires,

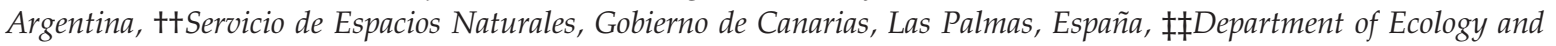 \\ Evolutionary Biology, University of California, Santa Cruz, CA, USA, §§Marine Biology Research Division, Scripps Institution \\ of Oceanography, University of California, San Diego, CA, USA, - Universidad de Las Palmas de Gran Canaria, Las Palmas, \\ Islas Canarias, España
}

\begin{abstract}
Among shallow water sea urchin genera, Arbacia is the only genus that contains species found in both high and low latitudes. In order to determine the geographical origin of the genus and its history of speciation events, we constructed phylogenies based on cytochrome oxidase I and sperm bindin from all its species. Both the mitochondrial and the nuclear gene genealogies show that Arbacia originated in the temperate zone of the Southern Hemisphere and gave rise to three species in the eastern Pacific, which were then isolated from the Atlantic by the Isthmus of Panama. The mid-Atlantic barrier separated two additional species. The bindin data suggest that selection against hybridization is not important in the evolution of this molecule in this genus. Metz et al. in a previous publication found no evidence of selection on bindin of Arbacia and suggested that this might be due to allopatry between species, which obviated the need for species recognition. This suggestion formed the basis of the conclusion, widely spread in the literature, that the source of selection on sea urchin bindin (where it does occur) was reinforcement. However, the range of Arbacia spatuligera overlaps with that of two other species of Arbacia, and our data show that it is hybridizing with one of them. We found that even in the species that overlap geographically, there are no deviations from selective neutrality in the evolution of bindin.
\end{abstract}

Keywords: gametic isolation molecules, Isthmus of Panama, marine barriers, mitochondrial DNA, speciation

Received 14 July 2011; revision received 26 August 2011; accepted 30 August 2011

\section{Introduction}

As a rule, shallow water epifaunal sea urchin genera are either entirely tropical or entirely temperate, with limited overlap in the subtropics. This separation has important biogeographical consequences, because

Correspondence: H. A. Lessios, Fax: +507 212 8790;

E-mail: lessiosh@post.harvard.edu

${ }^{1}$ Present address: Science Applications International Corporation, MD, USA. today's oceans are connected only at high latitudes. Thus, shallow water marine taxa that are strictly tropical are prevented by physical barriers and thermal tolerances from spreading between ocean basins. Yet, each tropical sea urchin genus contains species in more than one ocean, because such contacts were possible in the past. The Tethys Sea in the Northern Hemisphere had connected the Indo-Pacific with the Atlantic until the Middle Miocene (Rögl \& Steininger 1984; Vrielynck et al. 1997). An alternate route around the southern tip 
of Africa became blocked for tropical organisms by the onset of the Benguela upwelling off the South-west coast of Africa in the Late Miocene and the Pliocene (Meyers et al. 1983; Marlow et al. 2000). Most shallow water taxa in the tropical eastern Pacific have been isolated from the rest of the Indo-Pacific for the greater part of the Cenozoic by the eastern Pacific barrier, $5000 \mathrm{~km}$ of deep water with no stepping stones (Grigg \& Hey 1992; but see Lessios et al. 1998, 2003; Lessios \& Robertson 2006). When the Isthmus of Panama was completed in the Pliocene (Coates \& Obando 1996), it became virtually impossible for any taxon that cannot survive in low temperatures to spread from one ocean to another (Lessios 2008), although there are a few known cases of leakage by tropical fishes around the southern tip of Africa (Bowen et al. 2001, 2006; Rocha et al. 2005). Thus, stenothermic tropical species in different oceans have evolved independently since the Pliocene. Among shallow water sea urchins, only one genus, Arbacia, is found in both low and high latitudes and thus has the potential of maintaining gene flow between ocean basins.

Arbacia contains six extant species. Arbacia lixula is common throughout the Mediterranean Sea and also occurs on the African Atlantic coast, ranging south to Angola (Mortensen 1935: 572). It is also found on the other side of the Atlantic; whereas in the eastern Atlantic it occupies mostly the Northern Hemisphere, in the western Atlantic it occurs only in the Southern Hemisphere, on the coast of Brazil. It inhabits the littoral zone, down to $5 \mathrm{~m}$. In the Northern Hemisphere of the western Atlantic, A. lixula is replaced by Arbacia punctulata, which ranges from Cape Cod to Suriname, with a bathymetrical distribution from the intertidal to $225 \mathrm{~m}$ (Mortensen 1935: 575). This species is rare in the Caribbean. In the eastern Pacific, there are three species. Arbacia stellata $(=A$. incisa) is found from Baja California to Peru at <10 m depth (Mortensen 1935: 577). Arbacia spatuligera occurs from Guayaquil in Ecuador to Puerto Montt in southern Chile at $<25 \mathrm{~m}$ depth. The distribution of Arbacia dufresni begins at Puerto Montt and continues around Tierra del Fuego into the South-West Atlantic to Patagonia and the Falkland Islands (Malvinas) from 0 to $315 \mathrm{~m}$ (Mortensen 1935: 580). This is the only species of Arbacia found on both sides of South America. It also occurs at Booth (Wandel) Island on the coast of Antarctica. Mortensen (1910) described an additional species, Arbacia crassispina, which he considered endemic to Tristan da Cunha, half-way between South America and South Africa, but we have also encountered specimens conforming to his description in the Falkland Islands. Thus, Arbacia is unique among epifaunal shallow water echinoid genera in containing species that extend from the northern temperate zone into the tropics, and also species in the Southern Hemisphere that are restricted to the temperate and sub-Antarctic zones. The barriers that may have caused speciation in this genus are likely to be different from those that caused speciation in strictly tropical echinoid genera, such as Echinometra (McCartney et al. 2000; Landry et al. 2003), Diadema (Lessios et al. 2001), Lytechinus (Zigler \& Lessios 2004), Tripneustes (Lessios et al. 2003), or Eucidaris (Lessios et al. 1999), because - judging by its modern distribution - it is a taxon with much wider thermal tolerances. Mayr (1954) speculated that the species of Arbacia are so old, that evidence of the pattern of their speciation is no longer reflected in present-day ranges [see also Palumbi \& Lessios (2005)], but it is equally possible that something in the history of the genus may account for the odd distribution of its species. Alternatively, the apparent nonconformity to the zoogeographical pattern of other sea urchins may be a taxonomic artefact if tropical and low-latitude species have been included in the same genus even though they belong to different clades.

A phylogeny of four species of Arbacia was published by Metz et al. (1998). They used partial sequences of cytochrome oxidase I (COI) to establish the relationships between the species and to compare the mitochondrial DNA phylogeny with the genealogy of the bindin gene. Bindin is a molecule that coats the acrosome process of the sperm and mediates binding and fusion with the egg membrane. In some genera of sea urchins, it is recognized in a species-specific manner by the egg receptor, and in some genera, it evolves under strong selection (review in Zigler 2008). This is not the case in Arbacia; Metz et al. found no evidence of selection in the ratio of amino acid replacement to silent substitutions of this molecule. They also documented that A. stellata and A. punctulata can cross-fertilize indiscriminately in the laboratory. As the primary objective of Metz et al. was to study the evolution of the bindin molecule, they used few sequences from each species and did not root the COI and bindin phylogenetic trees. They also considered all species of Arbacia as allopatric. The absence of selection on bindin of Arbacia (with generally allopatric species) and the presence of strong selection in Echinometra (Metz \& Palumbi 1996; McCartney \& Lessios 2004), Strongylocentrotus (Biermann 1998) and Heliocidaris (Zigler et al. 2003) (which contain sympatric species) led to the hypothesis that species recognition and avoidance of hybridization were the selective forces acting on bindin (Swanson \& Vacquier 2002; Geyer \& Palumbi 2003; Zigler \& Lessios 2003; McCartney \& Lessios 2004; Lessios 2007; Zigler 2008; Geyer \& Lessios 2009; Levitan \& Stapper 2010). There is, however, evidence that one species of Arbacia is sympatric with two others. On the Pacific coast of South 
America, the range of $A$. spatuligera overlaps with that of A. stellata in the North and that of $A$. dufresni in the South. For example, A. spatuligera and A. stellata are both found on the islands of Lobos de Afuera in northern Peru (Hooker et al. 2005), and A. spatuligera and A. dufresni are both found in Puerto Montt in Chile (Lorrain 1975). One of the objectives of the present study is to determine whether bindin of $A$. spatuligera shows evidence of having evolved under selection, which would be expected if avoidance of hybridization (reinforcement) has resulted in selective pressures on this molecule.

In this study, we use partial sequences of $\mathrm{COI}$ and complete sequences of the mature sperm bindin molecule to address the following questions: (i) Are all the species of Arbacia described on the basis of morphology also reflected in gene genealogy? (ii) Where did the genus originate and what are the phylogenetic relationships between its species? (iii) When did speciation occur, and what barriers might have caused it? (iv) On the basis of the phylogeny, is it possible to subdivide the genus in a way that would separate low- from highlatitude species? (v) Is there evidence of selection on bindin of the species of Arbacia that are partially sympatric?

\section{Materials and methods}

\section{Collection of specimens}

We collected 256 individuals of Arbacia from 28 localities, representing all six described species of the genus: 14 of Arbacia crassispina from Tristan da Cunha and the Falkland Islands; 46 of Arbacia dufresni from the Atlantic coast of Patagonia, the Falklands, Tierra del Fuego and Chile; 15 of Arbacia spatuligera from Peru; 22 of Arbacia stellata from Peru, Panama, El Salvador and Baja California; 19 of Arbacia punctulata from the Caribbean, Florida and North Carolina; and 140 of Arbacia lixula from Cape Verde, the Canaries, Madeira, the Azores, Brazil, and from eight locations in the Mediterranean (Fig. 1). Four individuals of the arbacioid Tetrapygus niger were collected from Chile or Peru to serve as outgroups. The only geographical region in the range of Arbacia that is not represented in our collections is the west coast of Africa, South of Cape Verde, where the 'variety' A. lixula africana occurs (Mortensen 1935: 572). Samples were preserved in $95 \%$ ethanol or in high-salt DMSO buffer (Seutin et al. 1991).

\section{DNA extraction and sequencing}

We carried out genomic DNA extractions, polymerase chain reaction (PCR) amplifications, PCR product purifi- cation and DNA sequencing of a partial COI region as described by Lessios et al. (1996), with one modification: Primers used in the forward direction were either CO1-f 5' CCTGCAGGAGGAGGAGAYCC or CO1-p 5'GGTCACCCAGAAGTGTACAT. CO1-a 5' AGTATAAGCGTCTGGGTAGTC was used as the reverse primer. These primers amplified up to 670 nucleotides of the COI region. Using the amplification primers for cycle sequencing, we sequenced in both directions, at least once for each strand, using automatic sequencers from Applied Biosystems.

Sequences of the mature bindin molecule were obtained from the data of Metz et al. (1998) (GenBank accession no. AF030825.1-AF030829.1, AF030831.1, AF030833.1， AF030835.1, AF030837.1, AF030839.1, AF030841.1, AF030843.1, AF030845.1, AF030847.1, AF030849.1, AF030851.1, AF030853.1, AF030855.1, AF030857.1), augmented with new sequences from two individuals of $A$. crassispina, three of $A$. spatuligera, four of $A$. dufresni and one of T. niger. The methods of Metz et al. were used to amplify the two bindin exons of mature bindin using their primers AMBF3 and AMBR2 and Flexi-Go ${ }^{\circledR}$ Taq polymerase (Promega). Amplicons were cloned using the $\mathrm{pGEM}^{\circledR}$-T Easy Vector System II (Promega), then cycle-sequenced using M13 (GTAAAACGACGGCCAG) and M13R (GGAAACAGCTATGACCATG) primers. One clone from each individual was sequenced in one direction, except for one individual of $A$. dufresni and one of $A$. spatuligera from Bahia Corral, Chile, in which five clones from each specimen were sequenced. One of these individuals proved to be homozygous and the other heterozygous. Intron sequences were not used in our analysis. The complete mature bindin of Arbacia is $705 \mathrm{bp}$ long. The new bindin sequences have been deposited in GenBank under accession numbers JF773135-JF773144.

\section{Phylogenetic reconstruction}

We employed Posada's (2008) JMODELTEST program v. 0.1.1 to determine the simplest model of mitochondrial DNA (mtDNA) and of bindin evolution that produced the best fit of the data to the tree, based on the AIC criterion (Akaike 1974). This condition was satisfied by the general time-reversible model (Tavare 1986) with a gamma correction $(\alpha=1.0239)$ and a proportion of invariable sites $(P=0.5127)$ for the COI data $(G T R+I+G)$. For bindin, the best model for the first exon was a GTR $+\mathrm{I}+\mathrm{G}$ model with $\alpha=0.3490$ and $P=0.5360$, but with four rate categories (TPM3u$f+I+G)$. For the second exon of bindin, the best model was that of Tamura \& Nei (1993) with a gamma correction $(\alpha=0.5920)$ and a proportion of invariable sites $(P=0.7230)(\operatorname{TrN}+\mathrm{I}+\mathrm{G})$. 


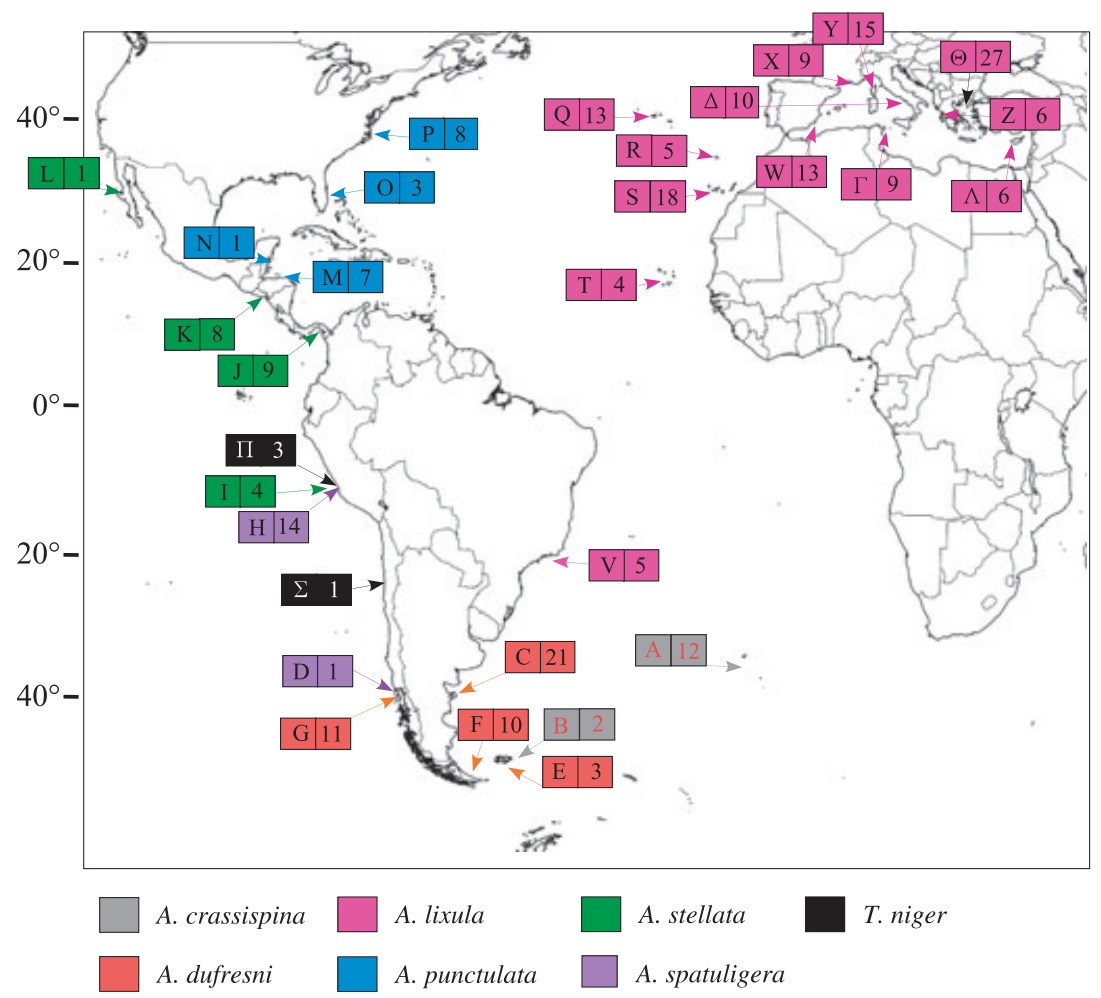

Fig. 1 Collection localities of specimens used in this study. Colours indicate the species as determined from morphology or nuclear DNA sequences; letters indicate localities, and numbers sample size. Grey: Arbacia crassispina - A: Tristan da Cunha; B: Falkland Islands (Malvinas). Red: Arbacia dufresni - C: Puerto Madryn, Chubut Province, Patagonia; E: Falkland Islands (Malvinas); F: Beagle Channel, Tierra del Fuego, Argentina; G: Puerto Montt, Bahia Metri, and Bahia Corral, Chile. Purple: Arbacia spatuligera - H: Pisco, Peru; D: Bahia Corral, Chile. Green: Arbacia stellata - I: Acapulco, Peru; J: Bay of Panama; K: Acajutla and Golfo de Fonseca, El Salvador; L: Guerrero Negro, Baja California. Blue: Arbacia punctulata - M: Cayos Cochinos, Honduras; N: Carrie Bow Cay, Belize; O: Ft. Pierce, Florida; P: Beaufort, North Carolina. Violet: Arbacia lixula - Q: Faial, Azores; R: Reis Magos, Madeira; S: Gran Canaria and La Palma, Islas Canarias; T: Sal Island, Cape Verde; V: Baia Sepetiba Rio de Janeiro, Brazil; W: Alicante, Spain; X: Marseille, France; Y: Corsica; Z: Parga, Ionian Sea; $\Gamma$ : Tunis; $\Delta$ : Napoli, Italy; $\Theta$ : Alexandroupolis, Chalkidiki Peninsula, and Samothraki, North Aegean Sea; $\Lambda$ : Akamas Peninsula, Cyprus. Black: Tetrapygus niger - П: Paracas, Peru; $\Sigma$ : Coquimbo, Chile.

Cytochrome oxidase I and bindin phylogenies were constructed using version 3.1.2 of MRBAYES (Ronquist \& Huelsenbeck 2003), applying each of the models suggested by JMODELTEST. For bindin, the two exons were considered as separate partitions, with a separate model of DNA evolution applied to each. The analysis of COI was started with Dirichlet priors for rates and nucleotide frequencies and fixed rates for the gamma shape parameter and the proportion of invariable sites. The run consisted of estimating $40 \times 10^{6}$ trees, sampling every 100th tree, and calculating credibility values of the nodes of the $50 \%$ majority rule tree after discarding the first $10^{5}$ trees. The analysis of the bindin molecule was started with fixed priors for each partition for all parameters, as estimated from JMODELTEST, and consisted of estimating $20 \times 10^{6}$ trees, sampling every 100th tree, and calculating credibility values of the nodes of the $50 \%$ majority rule tree after discarding the first $5 \times 10^{4}$ trees. In both analyses, the heating parameter $\mathrm{T}$ was set at 0.01 , and there were two parallel runs, each with four chains. Convergence was determined by a value of average standard deviation of split frequencies $<0.01$, by a value of potential reduction factor equal to 1 for all parameters and by multiple runs that produced the same topology. As MrBAYES will only accept a single taxon as an outgroup, a single COI sequence of $T$. niger was randomly chosen for the analysis. Identical COI haplotypes were removed before being submitted to MrBAyES.

We also constructed COI and bindin gene genealogies by maximum likelihood (ML), using the program GARLI v. 0.95 (Zwickl 2006; https://www.nescent.org/wg garli/Main_Page). The COI data were analysed with the same model of DNA evolution as the MrBAYES analysis, with all parameters fixed. The bindin data were analysed with a GTR + G + I model in which rates, nucleotide frequencies, the $\alpha$ parameter of the $\Gamma$ distribution and the per cent invariant sites were all esti- 
mated. One thousand bootstrapped trees were generated from each set of data, and a 50\% majority consensus tree was contracted in v. 4.0 PAUP*.

To estimate times since divergence between the species, we used the penalized-likelihood method of Sanderson (2002), as implemented in his program r8s v. 1.70 (Sanderson 2004). Because the program cannot produce reliable results from more than 35 sequences, the COI tree obtained from MRBAYES was pruned to include only two sequences per well-supported clade. Smoothing parameters were determined by the cross-validation procedure provided by the program and applied as penalty functions for changes in the logarithms of the rates. We also used the mean path length method of Britton et al. (2002, 2007), as implemented in their program PATHD8 v. 1.0. This method calculates time since divergence by using the mean path lengths between each node and terminal taxa that descend from it, after locally smoothing substitution rates. It performs a test of the local molecular clock for the descendants of each node and calculates confidence intervals by assuming that substitutions follow a Poisson distribution. This analysis was carried out without pruning of the trees.

To estimate rates of evolution of COI and bindin, we have assumed that the eastern Pacific A. stellata was split from the Atlantic clade encompassing A. punctulata and A. lixula at the final closure of the Isthmus of Panama, approximately 3 million years ago (Ma) (Coates \& Obando 1996). We have further constrained the estimates in both r8s and PATHDs by those suggested by fossil evidence (Smith 2005). The end of the Miocene (5.3 Ma) was considered as a minimum age for the split between Arbacia and Tetrapygus, and the end of the Pliocene (2.6 Ma) was considered as the minimum age for the divergence of $A$. punctulata from A. lixula.

\section{Evolution of bindin}

Metz et al. (1998) found no evidence of selection on the bindin of A. lixula, A. punctulata, A. stellata and A. dufresni. In order to determine whether the same holds true on the mature bindins of $A$. spatuligera despite the overlap of its geographical range with that of $A$. stellata and $A$. dufresni, we conducted tests in the Codeml module of PAML v. 4.4 (Yang 2007). For this analysis, the tree of all bindin alleles (except for three from Bahia Corral, suspected to belong to hybrid individuals) was unrooted, and 27 nucleotide sites containing gaps or ambiguities were eliminated. The resulting 226 amino acid alignment was subjected to analysis of the distribution of the ratio of amino acid replacement to silent substitutions $(\omega)$ among sites and among branches. Site-specific models described by Yang (1998), Yang et al. (2000) and Wong et al. (2004) were used. As null models for varia- tion between sites we used the nearly neutral (M1a) and the $\beta$ distribution (M7) model. As a model that allows selection, we used the $\beta+\omega$ model (M8), which allows for a continuous distribution of $\omega$ values across sites. We also used branches-site models (Yang \& Nielsen 2002; Yang et al. 2005; Zhang et al. 2005) for a simultaneous examination of variation in selection among amino acid sites and among lineages of bindin. Model MA1 assumed that the amino acid replacement to silent substitution ratios $\left(\omega_{0}=\mathrm{d}_{\mathrm{N}} / \mathrm{d}_{\mathrm{S}}\right)$ for all background branches varied between 0 and 1, whereas the foreground ratio was free to vary and was compared with the nearly neutral model M1a. This test can produce significant results if there is relaxation of constraints, rather than positive selection, in the foreground branch. Model MA2 is similar to MA1, but uses as the null model MA1 with the foreground $\omega=1$, and is thus considered a direct test of positive selection (Zhang et al. 2005). Model MB allows all $\omega$ parameters to be estimated from the data. In all tests, bindin alleles of A. spatuligera were considered as the 'foreground' and all other sequences of Arbacia as the 'background'. Because recombination can produce spurious signatures of selection (Anisimova et al. 2003; Shriner et al. 2003), we used DNAsP v. 5.10 .1 (Librado \& Rozas 2009) to estimate the recombination parameter $\mathrm{R}$ (Hudson \& Kaplan 1985) and to perform the four-gamete test (Hudson 1987) for estimating the minimum number of recombination events.

\section{Results}

\section{Phylogeography}

The 257 COI sequences of Arbacia produced 177 unique haplotypes. Figure 2A and 2B depict their phylogeny. Bayesian and maximum-likelihood algorithms produced the same topology, although bootstrapping of the ML tree produced only weak support (0.53 and 0.54$)$ for the monophyly of sequences in two major clades that had high Bayesian credibility values (0.96 and 1.00). The gene genealogy shows that mitochondrial sequences of recognized species are monophyletic, but there are two exceptions. (i) One individual with Arbacia dufresni morphology from Bahia Corral in southern Chile had mtDNA that grouped with Arbacia spatuligera. COI of this individual was sequenced twice from separate extractions to ensure that the wrong species assignment was not due to PCR contamination. Both bindin alleles from the same individual ('A. dufresni Bahia Corral 1', Fig. 2A) were in the same clade as bindin from $A$. $d u f-$ resni. In this individual $A$. spatuligera mtDNA is residing in $A$. dufresni nuclear background. The most likely explanation for this phenomenon is that there was 


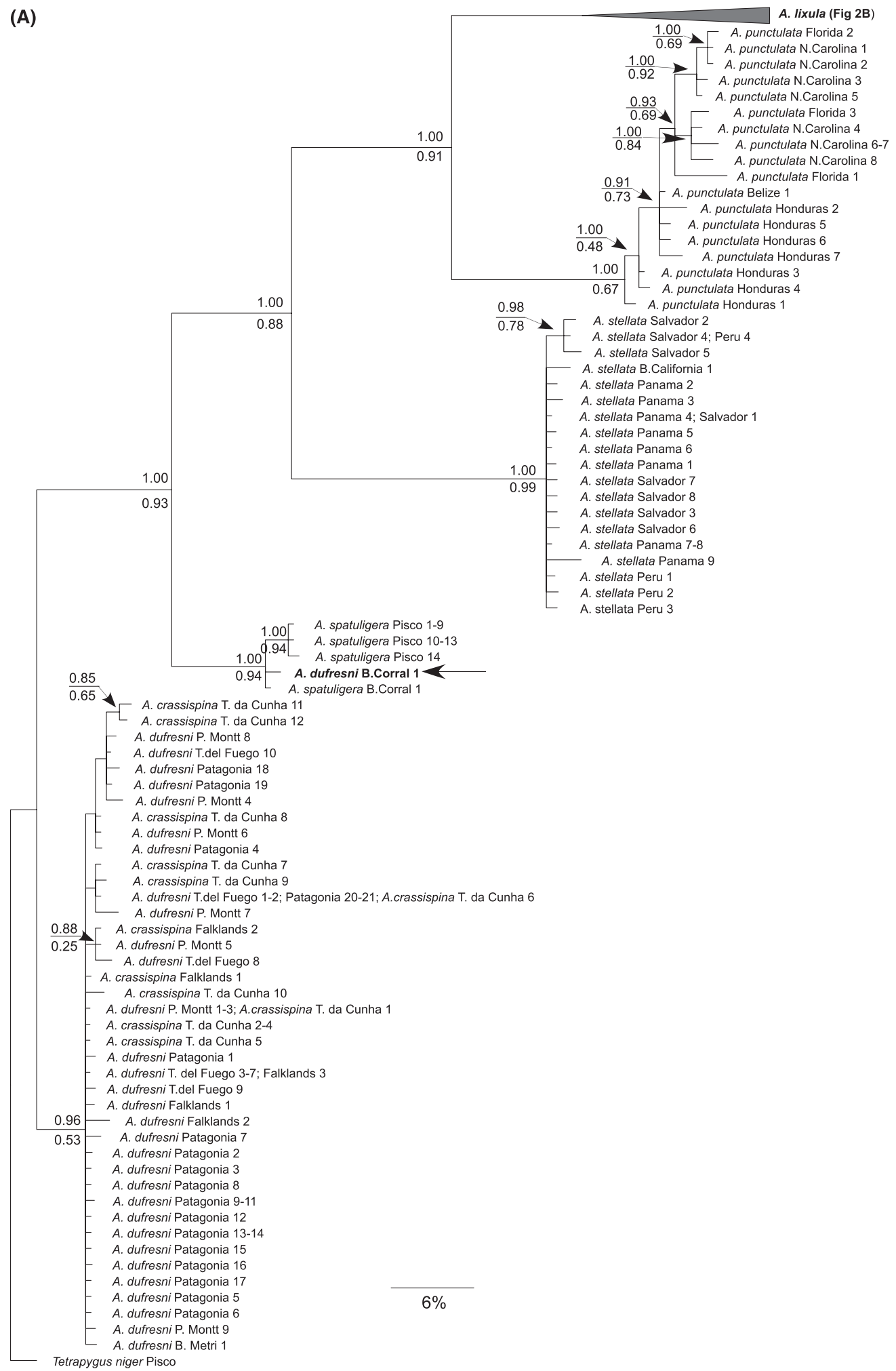

Fig. 2 Phylogeny of the sequences of cytochrome oxidase I (COI) of Arbacia, reconstructed with MrBAYEs. Credibility values from MRBAYES, when $>0.85$, are shown above the nodes, bootstrap values from GARLI below. (A) Haplotypes of Arbacia crassispina, Arbacia dufresni, Arbacia spatuligera, Arbacia stellata and Arbacia punctulata. Arrow indicates the specimen with A. spatuligera COI, but two alleles of $A$. dufresni bindin. (B) Haplotypes of Arbacia lixula. Numbers after locality names indicate individuals with indistinguishable haplotypes.

Published 2011. This article is a U.S. Government work and is in the public domain in the USA. 
136 H. A. LESSIOS ET AL.

(B)

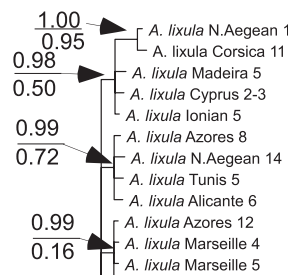

0.16 A. lixula Marseille 4

A. lixula Marseille 5

1.00
0.82 $\quad\left[\begin{array}{c}0.99 \\ 0.44\end{array}\left[\begin{array}{c}\text { A. lixula Brazil 1-2 } \\ \text { A. lixula Brazil 3 } \\ \text { A. lixula Brazil 4 }\end{array}\right.\right.$

$0.44-\left[\begin{array}{l}\text { A. lixula Canaries } 12 \\ \text { A. lixula Canaries } 14\end{array}\right.$

$1.00 \quad\left[\begin{array}{c}\text { A. Iilua Canes } 14 \\ 0.67\end{array}\right.$

0.67 A. lixula Azores 2

0.88 A. lixula Corsica 14

0.45 A. lixula Canaries 8-9

A. lixula lonian 4

$0.90 \quad[$ A. lixula Marseille 3

0.61 A. lixula Marseille 7

0.87 A. lixula Marseille 8

$\frac{0.87}{0.61}$ A. lixula Tunis 7

A. lixula Alicante 4

A. lixula Azores 3- 4

A. lixula Azores 1

A. lixula Azores 6-7; Canaries 6-8; Madeira 1; N.Aegean 1-2; Naples 11; Alicante 12-13

A. lixula Azores 10

A. lixula Azores 11

A. lixula Azores 13, Naples 1

A. lixula Azores 5

A. lixula Azores 9

A. lixula Canaries 6; Corsica 1-5; Marseille 1; N. Aegean 3-5; Alicante 7-11

A. lixula Canaries 7

A. lixula Canaries 10

A. lixula Canaries 11

A. lixula Canaries 5; Madeira 2

A. lixula Madeira 3

A. lixula Madeira 4 .

A. lixula Cyprus 4-5;

A. lixula Cyprus 6

A. lixula Cyprus 1

A. lixula Marseille 2

A. lixula Marseille 6

A. lixula Marseille 9

A. lixula N.Aegean 26 lixula N.Aegean $5-8 ;$ Alicante 12

A. lixula N.Aegean 5-8;

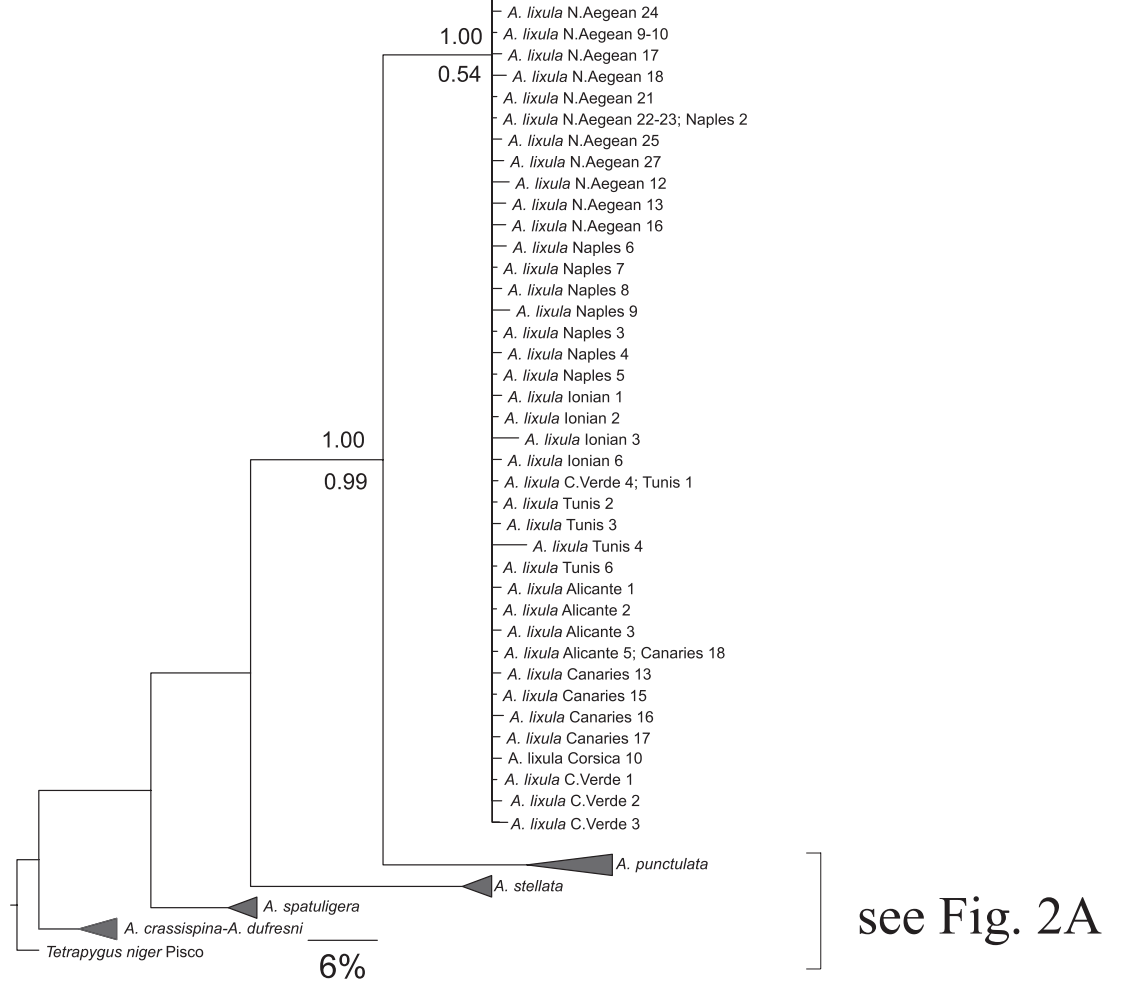

Fig. 2 Continued.

Published 2011. This article is a U.S. Government work and is in the public domain in the USA. 
hybridization between the two species. The only other individual in our sample from the same locality (A. spatuligera Bahia Corral 1, Fig. 2A) had mtDNA of A. spatuligera and bindin that resembled that of $A$. spatuligera. (ii) The second exception to monophyly of the nominal species was that there was no phylogenetic separation of COI from $A$. dufresni and A. crassispina. Indeed, the two morphospecies shared indistinguishable COI haplotypes; three individuals of $A$. dufresni from the eastern Pacific shared the same haplotype with one individual of $A$. crassispina from the Atlantic.

The Bayesian and ML topologies of the gene genealogy of bindin (Fig. 3) agreed with each other. The tree of bindin agreed with that of COI, with two exceptions. (i) Bindin of the individual from Bahia Corral with A. spatuligera mtDNA (A. spatuligera B. Corral 1, Fig. 2A) was most closely aligned with that of two individuals of $A$. spatuligera from Peru, but formed a separate clade, though with weak support from ML bootstrapping. (ii) Whereas in the mitochondrial phylogeny the Brazilian clade of $A$. lixula was a monophyletic entity within a polytomy of other sequences of this species, bindin of eastern Atlantic and Brazilian specimens was reciprocally monophyletic. In bindin, as in COI, A. crassispina and A. dufresni did not form separate clades.

The two methods used to estimate times of divergence between the species provided consistent results for the more recent splitting events, but the estimates of the age of $A$. spatuligera and $A$. dufresni obtained by PATHD8 from the COI tree were older than those obtained by the same method from the bindin tree or from either molecule by r8s (Fig. 4). Nevertheless, it can be concluded that the extant species of Arbacia did not split much before $5 \mathrm{Ma}$.

With Tetrapygus niger as the outgroup, both the COI and the bindin phylogenies showed that the earliest splits in the genus were between the eastern Pacific species. The $A$. dufresni-Arbacia crassispina complex split from all other extant species first 2.9-5.5 Ma, followed by separation of $A$. spatuligera $2.8-5.2 \mathrm{Ma}$, and then $A r$ bacia stellata 2.6-3.7 Ma (Fig. 4). The latter species was sister to the Atlantic clade, which subsequently diverged 1.5-3.3 Ma into two clades, that of Arbacia punctulata on the North coast of America and of A. lixula in the eastern Atlantic, the Mediterranean and Brazil. The Brazil population was a monophyletic unit nested within the rest of the haplotypes of $A$. lixula in COI (thus no date can be inferred from the mtDNA data), but reciprocally monophyletic in bindin, rendering an estimated date of splitting 1.9-3.3 Ma. There was no phylogenetic (Figs 2 and 3) distinction between the Mediterranean and the eastern Atlantic populations of A. lixula. There was also no distinction between eastern Pacific and Atlantic populations of Arbacia dufresni.

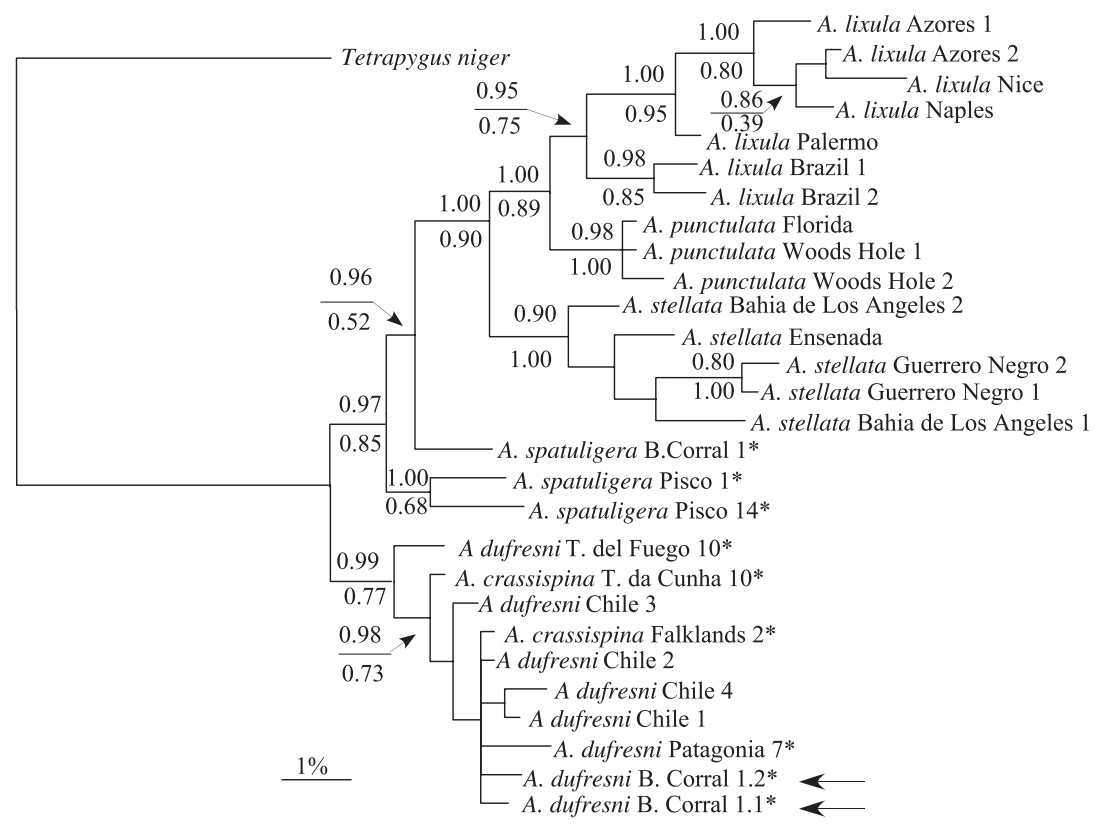

Fig. 3 Phylogeny of the sequences of bindin of Arbacia, reconstructed with MRBAYEs. Credibility values from MRBAYES, when $>0.85$, are shown above the nodes, bootstrap values from GARLI below. Arrows mark the two alleles of the specimen with Arbacia dufresni bindin, but Arbacia spatuligera cytochrome oxidase I (COI). Sequences from Metz et al. (1998) are identified with the same codes as in their publication. Asterisks identify sequences obtained for the present study. Codes of these specimens are the same as in Fig. 2. 


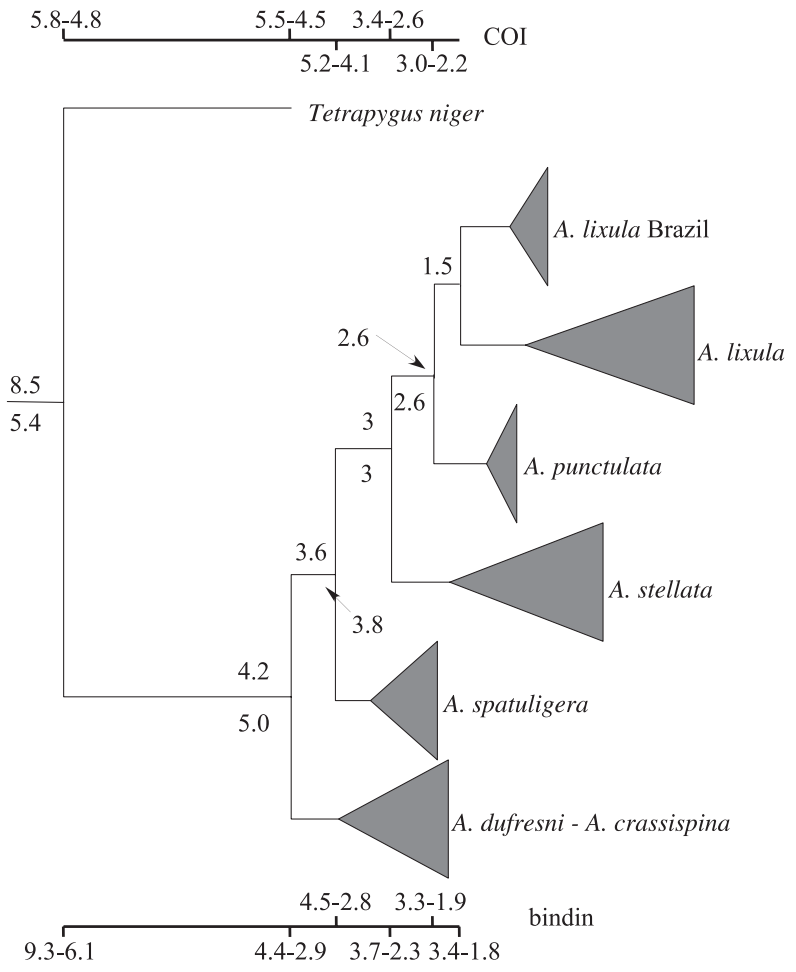

Fig. 4 Time since divergence of the clades of Arbacia in millions of years, as estimated under the assumption that Atlantic and Pacific clades were separated by the Isthmus of Panama $3 \mathrm{Ma}$ and constrained by a minimum age of the split between Arbacia and Tetrapygus of 5.3 Ma (end of the Miocene) and of Arbacia punctulata and Arbacia lixula of 1.6 Ma (end of the Pliocene). Values next to nodes indicate estimates from program r8s; values above the branches indicate ages obtained from bindin, below the branches those obtained from cytochrome oxidase I (COI). Ruler at the bottom indicates $95 \%$ confidence ranges of ages obtained from program PATHDs applied to the bindin data, and ruler at the top indicates confidence ranges applied to COI data.

\section{Mode of bindin evolution in geographically overlapping species}

The results of the PAML analysis for selection on the bindin of $A$. spatuligera (Table 1) indicated that the conclusions reached by Metz et al. (1998) for the four species they had included in their analysis applied to $A$. spatuligera as well. The comparison of model M7 vs. M8 showed that none of the amino acid sites of any of the species had an $\omega$ ratio larger than unity. The comparison of model M1a to either MA1 or MA2 and the comparison of MA1 to MA2, as well as the comparison of $\mathrm{M} 3$ to $\mathrm{MB}$, all indicated that the foreground branch did not show an excess of amino acid replacements over silent substitutions. Recombination in the bindin of $A r-$ bacia was high. Hudson's (1985) R per gene was 60.6, and the minimum number of recombination events
Table 1 Log-likelihood ratio tests comparing models allowing positive selection with their null alternatives

\begin{tabular}{llll}
\hline Models compared & $2 \Delta \ell$ & d.f. & $P$ \\
\hline Variable sites & & & \\
$\quad$ M7 vs. M8 & -0.113 & 2 & 0.945 \\
Branches/sites & & & \\
M1a vs. MA1 & -0.916 & 2 & 0.633 \\
M1a vs. MA2 & -0.916 & 3 & 0.822 \\
MA1 vs. MA2 & $-2 \times 10^{-6}$ & 1 & 0.999 \\
M3 $(k=2)$ vs. MB & -0.946 & 2 & 0.623 \\
\hline
\end{tabular}

$\Delta \ell$, likelihood ratio; d.f., degrees of freedom; $P$, probability derived from comparing the log-likelihood difference to the $\chi^{2}$ distribution. See text for description of the models.

from the four-gamete test was 14 . This level of recombination could have been a problem for the PAML analysis, because in some of the models, recombination can be misinterpreted as selection (Anisimova et al. 2003; Shriner et al. 2003). This, however, does not apply to an analysis that finds selection to be absent. Thus, despite the geographical overlap with $A$. stellata and $A$. dufresni, the bindin of $A$. spatuligera showed no evidence of having evolved under the influence of selection.

\section{Discussion}

The data presented here indicate that gene genealogies of Arbacia bindin, a nuclear gene, and COI, a mitochondrial gene, coincide, except for minor differences. The two genes are also in agreement in dismissing Arbacia crassispina as a species distinct from Arbacia dufresni. Estimates of time since divergence show that, contrary to what Mayr (1954) thought, the species of this genus are not particularly old. Two potential barriers that might have caused splitting between clades, the southern tip of the Americas, and the Straits of Gibraltar, have not done so in A. dufresni or in Arbacia lixula, respectively. Finally, the bindin of Arbacia spatuligera, despite the geographical overlap of this species with two other congeners and apparent hybridization with one of them, shows no evidence of selection.

Our Bayesian and ML bindin phylogenies of all species of Arbacia are compatible with the neighbour-joining phylogeny of four species by Metz et al. (1998). The major difference is that the addition of $A$. spatuligera and the rooting of our phylogeny between the $A$. spatuligera and the $A$. dufresni-A. crassispina clades show the latter as sister to all the other species of Arbacia. This is also true when our Bayesian and ML COI phylogenies are compared with the neighbour-joining COI phylogeny of Metz et al. (1998). The statement of Metz et al. that the clades of the two oceans split first and then each 
clade gave rise to the species within each ocean (a conclusion that cannot be reached on the basis of an unrooted tree) is not correct. An additional difference in the mitochondrial phylogenies is that whereas the finding of Metz et al. shows the Brazilian A. lixula as reciprocally monophyletic with respect the eastern Atlantic and Mediterranean populations of the same species, ours shows it as a monophyletic unit nested within a polytomy of haplotypes composed of the latter. The difference is not caused by the method of phylogenetic reconstruction, nor by the difference in the sequenced region of COI. It is caused by our much larger sample size of A. lixula, which has encompassed a great deal of the Mediterranean and eastern Atlantic variation in this gene. When we analysed with our methods our COI data, but with $A$. lixula represented only by samples from the Azores, Naples, Marseille and Brazil (the locations sampled by Metz et al.), the tree showed reciprocal monophyly between Brazilian and East Atlantic-Mediterranean haplotypes. A detailed analysis of population structure in A. lixula will be presented elsewhere.

With a rooted phylogeny, it is now possible to reconstruct the sequence of speciation events that has resulted in the present-day species of Arbacia. Barring extinctions, it is likely that the eastern Pacific Tetrapygus, the outgroup we have used, is actually the sister genus of Arbacia. The range of Tetrapygus niger, the only species in the genus, is from northern Peru to the Straits of Magellan (Lorrain 1975). The only other extant species of the order Arbacioida in the eastern Pacific is the abysal Dialithocidaris gemmifera (Maluf 1988). Although the possibilities that Arbacia split from an extant or extinct genus in the Atlantic or else from Indo-Pacific stock cannot be ruled out, the most parsimonious hypothesis is that it originated from a Tetrapygus-Arbacia common ancestor in the southeastern Pacific. The phylogeny and the modern distributions of the eastern Pacific species are also in agreement with this hypothesis, as the first clade to split from the rest is the southernmost $A$. dufresni-A. crassispina, followed by the Southern Hemisphere A. spatuligera, followed by the tropical eastern Pacific Arbacia stellata, then by the western Atlantic Arbacia punctulata and the eastern Atlantic A. lixula, which was then split from the Brazilian clade assigned by its morphology to the same species. The sequence of emergence of new species in the eastern Pacific follows the patterns of water circulation, as the West Wind drift meets the coast of Chile at about 40$45^{\circ} \mathrm{S}$, then it is deflected southward to form the Cape Horn system and northward to form the Humboldt current (Fernandez et al. 2000; Thiel et al. 2007). However, as with all phylogenetic reconstructions, ours reflects the sequence of splitting events, not of colonization of the various regions. The existence of Miocene fossils of
Arbacia at the eastern seaboard of North America (Smith 2005) makes it clear that the genus was widespread in two oceans long before the completion of the Isthmus of Panama-isolated Atlantic and Pacific clades.

The barriers that separated the three eastern Pacific species of Arbacia from one another and caused their speciation are hard to deduce. However, the distribution of each species of Arbacia in this region approximately corresponds with that of many other marine taxa, each falling in the three major biogeographical provinces diffusely defined by such distributions along the coast of Chile (Brattstrom \& Johanssen 1983; Lancellotti \& Vasquez 1999, 2000; Fernandez et al. 2000; Camus 2001). El Niño events, local upwelling, earthquakes, and disruption of the flow of the Humboldt Current by local topography characterize the coast of Chile and have drastic impacts on its fauna, including local extirpations (Thiel et al. 2007).

The eastern Pacific A. stellata is separated from the two Atlantic species by the mass of the American continent, so it is natural to assume that this split was brought about by the rise of the Isthmus of Panama (Coates \& Obando 1996; Lessios 2008). We have assumed here that this split occurred at the final closure of the water connections, $3 \mathrm{Ma}$, and we have calibrated rates of molecular evolution according to this assumption. It is, however, true that the value of transisthmian COI divergence in Arbacia is among the highest of sea urchin pairs similarly found on either side of Americas (Lessios 2008). Approximate Bayesian computation has shown that variation in divergence in seven species of sea urchins (including Arbacia) can be explained by the stochasticity of coalescence, not by earlier time of separation (Hickerson et al. 2006). The high transisthmian divergence value in COI of Arbacia is not reflected in equivalent values in its bindin exons (Lessios 2008). Nevertheless, the possibility exists that Atlantic and Pacific species of Arbacia were separated during the shoaling of the Isthmus at some date earlier than 3 million years. If so, the rates of molecular divergence we used for calibration are overestimates, and the true dates of the splitting between the species are older than the ones shown in Fig. 4. Even doubling the ages of the species, however, would not make them much older than species of Eucidaris (Lessios et al. 1999), Diadema (Lessios et al. 2001), Tripneustes (Lessios et al. 2003), Echinometra (McCartney et al. 2000) or Lytechinus (Zigler \& Lessios 2004). Thus, there is little support for Mayr's (1954) conclusion that the species of Arbacia are so old that evidence of their ancestral distributions has been lost.

The mid-Atlantic barrier, after separating the western A. punctulata from the eastern A. lixula, appears to have been crossed at least once to establish the latter on the 
coast of Brazil, then acted again to isolate this clade from the eastern Atlantic. It would be interesting to find out whether $A$. lixula africana from the western coast of Africa is more closely aligned to A. lixula from Cape Verde or to A. lixula from Brazil. Some tropical echinoids, such as Echinometra lucunter (McCartney et al. 2000; Geyer \& Lessios 2009) and Eucidaris tribuloides (Lessios et al. 1999), maintain genetic connections in the Southern Hemisphere between the coasts of Africa and of America, whereas others, such as Diadema antillarum (Lessios et al. 2001) and Tripneustes ventricosus (Lessios et al. 2003), do not.

There seems to be little doubt that $A$. crassispina and A. dufresni are not separate species, as the two morphs are not distinct in the phylogeny of either the mitochondrial or the nuclear gene. The morphological differences between the two nominal species are so slight, that Clark (1925) questioned whether they could be maintained as separate species. Mortensen (1935), the author of $A$. crassispina, agreed that it may be a local variety of A. dufresni, but then changed his mind (Mortensen 1941). Arbacia dufresni appears to be capable of very wide dispersal. That it crosses between oceans through the Magellan straits, the Beagle Channel, and around Tierra del Fuego is not all that surprising. Genetic signatures of potential barriers in this area have been found in sub-Antarctic patellid (Gonzalez-Wevar et al. 2010) and calyptraeid (Collin et al. 2007) gastropods, and also in Antarctic kelp (Fraser et al. 2009). But genetic contact around the tip of South America should not be a problem for a species, such as A. dufresni, spread from Patagonia to Tristan da Cunha with no apparent phylogenetic subdivision. Why there is no phylogenetic separation between COI sequences from the mainland and from Tristan da Cunha despite a distance of over $4000 \mathrm{~km}$ is not clear. Even though Tristan da Cunha is only 1 million years old, nearby Nightingale Island is 18 million years old (http:// www.btinternet.com/ sa_sa/tristan_da_cunha/tristan da_cunha.html), so propagules of Arbacia could have arrived in the area at any time of the history of the genus. It would appear that $A$. dufresni in the Archipelago has not been cut off from American populations at an ancient time. Given that $A$. dufresni is often associated with roots of bull-kelp, rafting of post-metamorphic individuals may be a possibility for dispersal (Thiel \& Haye 2006; Waters 2008). Another possibility is that the low temperatures associated with this part of the Atlantic retard the growth of the larvae and confer a long time in the plankton. Either type of propagule would be travelling on currents. There is vigorous water displacement from west to east in the southern Atlantic, but oceanographers disagree as to whether the South Subtropical Front and its associated South
Atlantic Current flows past Tristan da Cunha or stays South of it throughout the year (Stramma \& Peterson 1990; Lujeharms et al. 1993; Smythe-Wright et al. 1998).

Another potential barrier that does not appear to have caused any phylogenetic breaks is the Gibraltar Strait. This narrow opening - or more precisely the Almeria-Oran line inside the Mediterranean - has been shown to restrict gene flow in a number of organisms (e.g. Calderon et al. 2008; Sotelo et al. 2009; Zulliger et al. 2009; Perez-Portela et al. 2010; Vinas et al. 2010). This does not seem to be the case for A. lixula. It appears that planktonic larvae of Arbacia, perhaps because of the small egg size in this genus (George 1990; Lessios 1990), impart long periods of growth in the plankton. And yet, despite the high dispersal potential and the tolerance for low temperatures, the genus has apparently never crossed either the Eastern Pacific Barrier or the Benguela upwelling. Arbacia has never been reported from either live specimens or fossils from the Indo-Pacific.

Bindin in Arbacia shows no evidence of selection. This had been documented by Metz et al. (1998) for the species they had studied, and it remains true with the addition of our new sequences, despite the geographical overlap of $A$. spatuligera with $A$. stellata at one end of its distribution and with $A$. dufresni at the other. Metz et al. proposed three hypotheses as possible explanations for the low ratio of amino acid replacement to silent substitutions of Arbacia: (i) high levels of intraspecific gene flow, (ii) functional constraints of the molecular structure and (iii) species recognition. With the addition of new data, both those presented here about Arbacia and those that have been published since 1998 about the evolution of bindin, these possibilities can now be narrowed considerably: (i) The species of Arbacia may show high levels of genetic homogeneity between distant populations, but these are no higher than that of other species in which bindin is evolving under strong selection. For example, E. lucunter shows no significant population structure between Brazil, Ascension, St. Helena, and the coast of Africa (McCartney et al. 2000), yet its bindin evolves under strong selection (Geyer \& Lessios 2009). Lack of selection owing to high gene flow is, thus, an unlikely explanation. (ii) The bindin of Arbacia contains few insertions and deletions or glycine-rich repeats, both of which are present in the bindin of genera, such as Echinometra (Metz \& Palumbi 1996), Strongylocentrotus (Biermann 1998) and Heliocidaris (Zigler et al. 2003), which have been found to evolve under selection. The hypothesis that there is an association between these features of molecular structure and selection-driven evolution remains viable. We would still want to know, however, why different features of molecular structure came to 
evolve in different genera. (iii) Given our results from A. spatuligera, the hypothesis that absence of selection on bindin in Arbacia is because of the absence of need to avoid hybridization does not appear viable. There are additional reasons for doubting that reinforcement plays a role in the evolution of sea urchin bindin [reviews in Lessios $(2007,2011)]$. Even in Echinometra, in which a pattern of character displacement was demonstrated in the western Pacific (Geyer \& Palumbi 2003), it was later shown that no such pattern exists where it might have been expected in the Atlantic (Geyer \& Lessios 2009). Although we still do not exactly know the source of selection on bindin among genera with high replacement to silent substitutions, there is indirect evidence that it may arise from intraspecific processes, such as sexual selection (Palumbi 1999), or sexual conflict arising from interactions between sperm density and allele frequency (Levitan \& Ferrell 2006; Palumbi 2009; Levitan \& Stapper 2010). The question, of course, still remains: Why should sexual selection on bindin be strong in some genera and not in others? McCartney \& Lessios (2004) suggested that one would expect sexual selection in E. lucunter, because this species inhabits high-energy intertidal habitats and has a patchy distribution, thus encountering conditions of temporarily high sperm density. This, however, cannot be a general explanation, because $A$. lixula is also an intertidal species, yet its bindin evolves neutrally. It would appear that phylogenetic constraints play a role, because selection in bindin has only been found in members of the order Echinoida and has yet to be demonstrated in any other order (Zigler 2008).

\section{Conclusions}

The phylogeny of Arbacia is not in line with the tendency of marine species to arise in the tropics and then spread into the temperate zone [Jablonski et al. (2006), but see Williams (2007) for an example of transitions in both directions]. This nonconformity is not a taxonomic artefact. In the phylogenetic tree of Arbacia, one could potentially separate the low-latitude species from those that include populations in the tropics, but given the phylogenetic positions and geographical distributions of Arbacia lixula and Arbacia punctulata, there would be little point in doing so. The only strictly tropical species of Arbacia is Arbacia stellata. The pattern of substitutions among the bindin molecules of the species of Arbacia had provided the first evidence that this reproductive protein did not always evolve under strong selection. The new data presented here show that sympatry and avoidance of hybridization do not appear to be the deciding factors for the presence or absence of selection on bindin.

\section{Acknowledgements}

We thank A. and L. Calderon for help in the laboratory; J.M. Gonzalvez, P. Marcial, M.A. McCartney and S.T. Williams for collections; A.D Abreu, A. and N. Lessios and R. Ventura for help in the field; S.E. Coppard, A. Hiller and S.T. Williams for comments on the manuscript.

\section{References}

Akaike H (1974) A new look at the statistical model identification. IEEE Transactions on Automatic Control, 19, 716-723.

Anisimova M, Nielsen R, Yang ZH (2003) Effect of recombination on the accuracy of the likelihood method for detecting positive selection at amino acid sites. Genetics, 164, 1229-1236.

Biermann CH (1998) The molecular evolution of sperm bindin in six species of sea urchins (Echinoida: Strongylocentrotidae). Molecular Biology and Evolution, 15, 1761-1771.

Bowen BW, Bass AL, Rocha LA, Grant WS, Robertson DR (2001) Phylogeography of the trumpetfishes (Aulostomus): ring species complex on a global scale. Evolution, 55, 10291039.

Bowen BW, Muss A, Rocha LA, Grant WS (2006) Shallow mtDNA coalescence in atlantic pygmy angelfishes (Genus Centropyge) indicates a recent invasion from the Indian Ocean. Journal of Heredity, 97, 1-12.

Brattstrom H, Johanssen A (1983) Ecological and regional zoogeography of the marine benthic fauna of Chile. Sarsia, 68, 289-339.

Britton T, Oxelman B, Vinnersten A, Bremer K (2002) Phylogenetic dating with confidence intervals using mean path lengths. Molecular Phylogenetics and Evolution, 24, 5865.

Britton T, Anderson CL, Jacquet D, Lundqvist S, Bremer $\mathrm{K}$ (2007) Estimating divergence times in large phylogenetic trees. Systematic Biology, 56, 741-752.

Calderon I, Giribet G, Turon X (2008) Two markers and one history: phylogeography of the edible common sea urchin Paracentrotus lividus in the Lusitanian region. Marine Biology, 154, 137-151.

Camus PA (2001) Biogeografia marina de Chile continental. Revista Chilena de Historia Natural, 74, 587-617.

Clark HL (1925) A Catalogue of the Recent Sea Urchins (Echinoidea) in the Collection of the British Museum (Natural History). Oxford Univ. Press, London.

Coates AG, Obando JA (1996) The geologic evolution of the Central American Isthmus. In: Evolution and Environment in Tropical America (eds Jackson JBC, Coates AG, Budd A), pp. 21-56. Univ. of Chicago Press, Chicago, IL.

Collin R, Chaparro OR, Winkler F, Veliz D (2007) Molecular phylogenetic and embryological evidence that feeding larvae have been reacquired in a marine gastropod. Biological Bulletin, 212, 83-92.

Fernandez M, Jaramillo E, Marquet PA et al. (2000) Diversity, dynamics and biogeography of Chilean benthic nearshore ecosystems: an overview and guidelines for conservation. Revista Chilena de Historia Natural, 73, 797-830. 
Fraser CI, Nikula R, Spencer HG, Waters JM (2009) Kelp genes reveal effects of subantarctic sea ice during the Last Glacial Maximum. Proceedings of the National Academy of Sciences of the United States of America, 106, 3249-3253.

George SB (1990) Population and seasonal differences in egg quality of Arbacia lixula (Echinodermata: Echinoidea). Invertebrate Reproduction and Development, 17, 111-121.

Geyer LB, Lessios H (2009) Lack of character displacement in the male recognition molecule, bindin, in Altantic sea urchins of the genus Echinometra. Molecular Biology and Evolution, 26, 2135-2146.

Geyer LB, Palumbi SR (2003) Reproductive character displacement and the genetics of gamete recognition in tropical sea urchins. Evolution, 57, 1049-1060.

Gonzalez-Wevar CA, Nakano T, Canete JI, Poulin E (2010) Molecular phylogeny and historical biogeography of Nacella (Patellogastropoda: Nacellidae) in the Southern Ocean. Molecular Phylogenetics and Evolution, 56, 115-124.

Grigg RW, Hey R (1992) Paleoceanography of the tropical eastern Pacific Ocean. Science, 255, 172-178.

Hickerson MJ, Stahl EA, Lessios HA (2006) Test for simultaneous divergence using approximate Bayesian computation. Evolution, 60, 2435-2453.

Hooker Y, Solís-Marín FA, Lleellish M (2005) Equinodermos de las Islas Lobos de Afuera (Lambayeque, Perú). Revista Peruana de Biología, 12, 77-82.

Hudson RR (1987) Estimating the recombination parameter of a finite population model without selection. Genetical Research, 50, 245-250.

Hudson RR, Kaplan NL (1985) Statistical properties of the numberof recombination events in the history of a sample of DNA sequences. Genetics and Evolution, 111, 147-164.

Jablonski D, Roy K, Valentine JW (2006) Out of the tropics: evolutionary dynamics of the latitudinal diversity gradient. Science, 314, 102-106.

Lancellotti DA, Vasquez JA (1999) Biogeographical patterns of benthic macroinvertebrates in the Southeastern Pacific littoral. Journal of Biogeography, 26, 1001-1006.

Lancellotti DA, Vasquez JA (2000) Zoogeography of benthic macroinvertebrates of the Chilean coast: contribution for marine conservation. Revista Chilena de Historia Natural, 73, 99-129.

Landry C, Geyer LB, Arakaki Y, Uehara T, Palumbi SR (2003) Recent speciation in the Indo-West Pacific: rapid evolution of gamete recognition and sperm morphology in cryptic species of sea urchin. Proceedings of the Royal Society. Biological Sciences, 270, 1839-1847.

Lessios HA (1990) Adaptation and phylogeny as determinants of egg size in echinoderms from the two sides of the isthmus of Panama. American Naturalist, 135, 1-13.

Lessios HA (2007) Reproductive isolation between species of sea urchins. Bulletin of Marine Science, 81, 191-208.

Lessios HA (2008) The Great American Schism: divergence of marine organisms after the rise of the Central American Isthmus. Annual Review of Ecology Evolution and Systematics, 39, 63-91.

Lessios HA (2011) Speciation genes in free-spawning marine invertebrates. Integrative and Comparative Biology, 51, 456465.

Lessios HA, Robertson DR (2006) Crossing the impassable: genetic connections in 20 reef fishes across the eastern Pacific barrier. Proceedings of the Royal Society. Biological Sciences, 273, 2201-2208.

Lessios HA, Kessing BD, Wellington GM, Graybeal A (1996) Indo-Pacific echinoids in the tropical eastern Pacific. Coral Reefs, 15, 133-142.

Lessios HA, Kessing BD, Robertson DR (1998) Massive gene flow across the world's most potent marine biogeographic barrier. Proceedings of the Royal Society. Biological Sciences, 265, 583-588.

Lessios HA, Kessing BD, Robertson DR, Paulay G (1999) Phylogeography of the pantropical sea urchin Eucidaris in relation to land barriers and ocean currents. Evolution, 53, 806-817.

Lessios HA, Kessing BD, Pearse JS (2001) Population structure and speciation in tropical seas: global phylogeography of the sea urchin Diadema. Evolution, 55, 955-975.

Lessios HA, Kane J, Robertson DR (2003) Phylogeography of the pantropical sea urchin Tripneustes: contrasting patterns of population structure between oceans. Evolution, 57, 20262036.

Levitan DR, Ferrell DL (2006) Selection on gamete recognition proteins depends on sex, density, and genotype frequency. Science, 312, 267-269.

Levitan DR, Stapper AP (2010) Simultaneous positive and negative frequency-dependent selection on sperm bindin, a gamete recognition protein in the sea urchin Strongylocentrotus purpuratus. Evolution, 64, 785-797.

Librado P, Rozas J (2009) DnaSP v5: a software for comprehensive analysis of DNA polymorphism data. Bioinformatics, 25, 1451-1452.

Lorrain AP (1975) Los Equinoideos regulares fosiles y recientes de Chile. Gayana Zoologia (Chile), 35, 1-198.

Lujeharms JRE, Valentine HR, van Ballegooyen RC (1993) On the subtropical convergence in the South Atlantic Ocean. South African Journal of Science, 89, 552-559.

Maluf LY (1988) Composition and distribution of the centrla eastern Pacific echinoderms. Natural History Museum LA County, Technical Reports, 2, 1-242.

Marlow JR, Lange CB, Wefer G, Rosell-Mele A (2000) Upwelling intensification as part of the Pliocene-Pleistocene climate transition. Science, 290, 2288-2291.

Mayr E (1954) Geographic speciation in tropical echinoids. Evolution, 8, 1-18.

McCartney MA, Lessios HA (2004) Adaptive evolution of sperm bindin tracks egg incompatibility in neotropical sea urchins of the genus Echinometra. Molecular Biology and Evolution, 21, 732-745.

McCartney MA, Keller G, Lessios HA (2000) Dispersal barriers in tropical oceans and speciation of Atlantic and eastern Pacific Echinometra sea urchins. Molecular Ecology, 9, 13911400.

Metz EC, Palumbi SR (1996) Positive selection and sequence rearrangements generate extensive polymorphism in the gamete recognition protein bindin. Molecular Biology and Evolution, 13, 397-406.

Metz EC, Gomez-Gutierrez G, Vacquier VD (1998) Mitochondrial DNA and bindin gene sequence evolution among allopatric species of the sea urchin genus Arbacia. Molecular Biology and Evolution, 15, 185-195.

Meyers PA, Brassell SC, Huc AY et al. (1983) Organic geochemistry of sediments recovered by DSDP/IPOD leg 75 
from under the Benguela current. In: Coastal Upwelling. Its Sedimentary Record, Part B. Sedimentary Records of Ancient Coastal Upwelling (eds Thiede J, Suess E), pp. 453-466. Plenum Press, New York, NY.

Mortensen T (1910) Arbacia crassispina, sp. nov. Echinoidea of the Swedish South Polar Expedition, Lithographisches Institut des Generalstabs, Stockholm, p. 32.

Mortensen $\mathrm{T}$ (1935) A monograph of the Echinoidea. vII. Bothriocidaroida, Melonechinoida, Lepidocentroida and Stirodonta. C.A. Reitzel, Copenhagen.

Mortensen T (1941) Echinoderms of Tristan da Cunha. Results of the Norwegian Scientific Expedition to Tristan da Cunha 19371938, 7, 1-10.

Palumbi SR (1999) All males are not created equal: fertility differences depend on gamete recognition polymorphisms in sea urchins. Proceedings of the National Academy of Sciences of the United States of America, 96, 12632-12637.

Palumbi SR (2009) Speciation and the evolution of gamete recognition genes: pattern and process. Heredity, 102, 66-76.

Palumbi SR, Lessios HA (2005) Evolutionary animation: how do molecular phylogenies compare to Mayr's reconstruction of speciation patterns in the sea? Proceedings of the National Academy of Sciences of the United States of America, 102(Suppl. 1), 6566-6572.

Perez-Portela R, Villamor A, Almada V (2010) Phylogeography of the sea star Marthasterias glacialis (Asteroidea, Echinodermata): deep genetic divergence between mitochondrial lineages in the north-western mediterranean. Marine Biology, 157, 2015-2028.

Posada D (2008) jModelTest: phylogenetic model averaging. Molecular Biology and Evolution, 25, 1253-1256.

Rocha LA, Robertson DR, Rocha CR et al. (2005) Recent invasion of the tropical Atlantic by an Indo-Pacific coral reef fish. Molecular Ecology, 14, 3921-3928.

Rögl F, Steininger FF (1984) Neogene Paratethys, Mediterranean and Indo-Pacific seaways. Implications for the paleobiogeography of marine and terrestrial biotas. In: Fossils and climate (ed. Brenchley P), pp. 171-200. Wiley, New York, NY.

Ronquist F, Huelsenbeck JP (2003) MRBAYES 3: Bayesian phylogenetic inference under mixed models. Bioinformatics, 19, 1572-1574.

Sanderson MJ (2002) Estimating absolute rates of molecular evolution and divergence times: a penalized likelihood approach. Molecular Biology and Evolution, 19, 101-109.

Sanderson MJ (2004) r8s, version 1.70.

Seutin G, White BN, Boag PT (1991) Preservation of avian blood and tissue samples for DNA analyses. Canadian Journal of Zoology - Revue Canadienne de Zoologie, 69, 82-90.

Shriner D, Nickle DC, Jensen MA, Mullins JI (2003) Potential impact of recombination on sitewise approaches for detecting positive natural selection. Genetical Research, 81, 115-121.

Smith ABe (2005) The Echinoid Directory. World Wide Web electronic publication. Available from http://www.nhm. ac.uk/research-curation/projects/echinoid-directory/index.

Smythe-Wright D, Chapman P, Rae CD, Shannon LV, Boswell SM (1998) Characteristics of the South Atlantic subtropical frontal zone between 15 degrees $W$ and 5 degrees E. Deep-Sea Research Part I, Oceanographic Research Papers, 45, 167-192.
Sotelo G, Moran P, Posada D (2009) Molecular phylogeny and biogeographic history of the European Maja spider crabs (Decapoda, Majidae). Molecular Phylogenetics and Evolution, 53, 314-319.

Stramma L, Peterson RG (1990) The South Atlantic Current. Journal of Physical Oceanography, 20, 846-859.

Swanson WJ, Vacquier VD (2002) Reproductive protein evolution. Annual Review of Ecology and Systematics, 33, 161179.

Tamura K, Nei M (1993) Estimation of the number of nucleotide substitutions in the control region of mitochondrial DNA in humans and chimpanzees. Molecular Biology and Evolution, 10, 512-526.

Tavare S (1986) Some probabilistic and statistical problems in the analysis of DNA sequences. In: Lectures on Mathematics in the Life Sciences (ed. Miura RM), pp. 57-86. American Mathematical Society, Providence, RI.

Thiel M, Haye PA (2006) The ecology of rafting in the marine environment. III. Biogeographical and evolutionary consequences. Oceanography and Marine Biology - An Annual Review, vol. 44. Taylor and Francis, London, pp. 323-429.

Thiel M, Macaya EC, Acuna E et al. (2007) The Humboldt Current System of northern and central Chile. Oceanography and Marine Biology, vol. 45, Taylor \& Francis, London, pp. 195-344.

Vinas J, Bremer JRA, Pla C (2010) Phylogeography and phylogeny of the epineritic cosmopolitan bonitos of the genus Sarda (Cuvier): inferred patterns of intra- and interoceanic connectivity derived from nuclear and mitochondrial DNA data. Journal of Biogeography, 37, 557-570.

Vrielynck B, Odin GS, Dercourt J (1997) Miocene palaeogeography of the Tethys Ocean: potential global correlations in the Mediterranean. In: Miocene Stratigraphy: An Integrated Approach (eds Montanari A, Odin GS, Coccioni R), pp. 157-165. Elsevier, Amsterdam.

Waters JM (2008) Driven by the West Wind Drift? A synthesis of southern temperate marine biogeography, with new directions for dispersalism. Journal of Biogeography, 35, 417427.

Williams ST (2007) Origins and diversification of Indo-West Pacific marine fauna: evolutionary history and biogeography of turban shells (Gastropoda, Turbinidae). Biological Journal of the Linnean Society, 92, 573-592.

Wong WSW, Yang ZH, Goldman N, Nielsen R (2004) Accuracy and power of statistical methods for detecting adaptive evolution in protein coding sequences and for identifying positively selected sites. Genetics, 168, 1041-1051.

Yang ZH (1998) Likelihood ratio tests for detecting positive selection and application to primate lysozyme evolution. Molecular Biology and Evolution, 15, 568-573.

Yang Z (2007) PAML 4: a program package for phylogenetic analysis by maximum likelihood. Molecular Biology and Evolution, 24, 1586-1591.

Yang ZH, Nielsen R (2002) Codon-substitution models for detecting molecular adaptation at individual sites along specific lineages. Molecular Biology and Evolution, 19, 908917.

Yang ZH, Nielsen R, Goldman N, Pedersen AMK (2000) Codon-substitution models for heterogeneous selection pressure at amino acid sites. Genetics, 155, 431-449. 
Yang ZH, Wong WSW, Nielsen R (2005) Bayes empirical Bayes inference of amino acid sites under positive selection. Molecular Biology and Evolution, 22, 1107-1118.

Zhang JZ, Nielsen R, Yang ZH (2005) Evaluation of an improved branch-site likelihood method for detecting positive selection at the molecular level. Molecular Biology and Evolution, 22, 2472-2479.

Zigler KS (2008) The evolution of sea urchin sperm bindin. International Journal of Developmental Biology, 52, 791-796.

Zigler KS, Lessios HA (2003) Evolution of bindin in the pantropical sea urchin Tripneustes: comparisons to bindin of other genera. Molecular Biology and Evolution, 20, 220231

Zigler KS, Lessios HA (2004) Speciation on the coasts of the new world: phylogeography and the evolution of bindin in the sea urchin genus Lytechinus. Evolution, 58, 1225-1241.

Zigler KS, Raff EC, Popodi E, Raff RA, Lessios HA (2003) Adaptive evolution of bindin in the genus Heliocidaris is correlated with the shift to direct development. Evolution, 57, 2293-2302.

Zulliger DE, Tanner S, Ruch M, Ribi G (2009) Genetic structure of the high dispersal Atlanto-Mediterreanean sea star Astropecten aranciacus revealed by mitochondrial DNA sequences and microsatellite loci. Marine Biology, 156, 597610.

Zwickl DJ (2006) Genetic algorithm approaches for the phylogenetic analysis of large biological sequence datasets under the maximum likelihood criterion. PhD dissertation, The University of Texas at Austin, Austin.

\section{Data accessibility}

Sequences: GenBank under accession numbers JF772875JF773134.

Phylogenetic data: TreeBASE Study accession no. 11860. 